\title{
Thermal Processes of Titanomaghemite in Volcanic Rocks
}

\author{
Yositugu INOUE* \\ Department of Geology, Shinshu University, \\ Matsumoto, Japan \\ (Received October 12, 1981 ; Revised May 19, 1982)
}

\begin{abstract}
Detailed thermomagnetic, reflection microscopic and electron-probe microanalyzer studies of 27 selected, mostly andesitic rocks have indicated that partly maghemitized titanomagnetite decomposes at temperatures ranging from $200^{\circ}$ to $600^{\circ} \mathrm{C}$ to ilmenite, ilmeno-hematite, and titanomagnetite forming intergrowths of exsolution lamellae. The unmixed phases are then homogenized to titanomagnetite at temperatures between $500^{\circ}$ and $800^{\circ} \mathrm{C}$.

Difference in thermomagnetic curves in a cycle of heating and cooling between room temperature and $600^{\circ} \mathrm{C}$ is mostly owing to whether or not the mixing temperature is higher than $600^{\circ} \mathrm{C}$. If the mixing proceeds in the thermomagnetic cycle, the Curie temperature observed in a cooling cycle is much lower than the initial value, since titanium content in titanomagnetite increases with mixing of ilmenite and ilmenohematite caused by heating.

Size dependence of the mixing rate has also been revealed by thermal experiment with pulverized and separated specimens.
\end{abstract}

\section{Introduction}

Degree of low-temperature oxidation of titanomagnetite in a majority of volcanic rocks formed on land is usually low and heterogeneous (AKIMOTO and KuSHIRO, 1960; Sasajima, 1961 ; Katsura and Kushiro, 1961 ; SASAJima and MaEnaKa, 1973; Momose, unpublished). Oxidized titanomagnetite (titanomaghemite) occurs only along rims and cracks of its parent phase. Titanomaghemite is stable at room temperature but unstable at high temperatures and decomposes so that its magnetic properties are irreversible with a cycle of heating and cooling.

Two different processes of thermal decomposition have been proposed ; (1) titanomaghemite decomposes into a pair of titanomagnetite and ilmenohematite with equal $\mathrm{Ti}-\mathrm{Fe}$ ratio (OzIMA and LARSON, 1967), (2) it decomposes into intergrowth of magnetite and ilmenite with minor components of other Fe-Ti oxides (READMAN and O'REILLY, 1970; OZIMA and LARSON, 1970).

The author investigated the processes of thermal decomposition of ferromagnetic minerals and associated changes in magnetic properties of a number of rocks. Although environmental condition of heating was kept constant throughout the present study, various types of thermomagnetic behavior were observed. Origin of the variety of thermal behavior was thus carefully examined with well-controlled samples by magnetic, micro-

*Present address: Showa Information Systems Co. Ltd., Minato-ku, Tokyo, Japan. 
scopic and electron-probe microanalyzer techniques.

2. Thermomagnetic Analyses

\subsection{Samples}

One hundred and eighty-four rock samples were collected at 63 sites in 6 regions; Hakone volcanic area, Shidara Basin in Aichi Prefecture, Warabidaira in Yamanashi Prefecture, Kume-shima of the Ryukyu Islands, Enrei area in Nagano Prefecture, and Iwaine district in Toyama Prefecture.

Among these rocks, 27 samples consisting of 17 andesites, 6 dolerites, 3 basalts, and a dacite (Table 1) were selected under ore microscope. Each selected rock contains partially maghemitized titanomagnetite, but no deuteric intergrowths were found under reflection microscope with the highest magnification.

Table 1. Samples and thermomagnetic results.

\begin{tabular}{|c|c|c|c|c|c|c|c|}
\hline $\begin{array}{l}\text { Specimen } \\
\text { code }\end{array}$ & Rocks* & longitude & latitude & $\begin{array}{l}J_{\mathrm{s}}-T \\
\text { type }\end{array}$ & $J_{2} / J_{1}$ & $\begin{array}{c}\text { Initial } \\
T_{\mathrm{C}}\left({ }^{\circ} \mathrm{C}\right)\end{array}$ & $\begin{array}{c}\text { Reduced } \\
T_{\mathrm{C}}\left({ }^{\circ} \mathrm{C}\right) \\
\end{array}$ \\
\hline HK13 & A. & $139^{\circ} 8.6^{\prime} \mathrm{E}$ & $35^{\circ} 12.5^{\prime} \mathrm{N}$ & \multirow{8}{*}{ A-I } & 0.83 & 565 & 470 \\
\hline HK39 & A. & $139^{\circ} 3.2^{\prime}$ & $35^{\circ} 11.9^{\prime}$ & & 0.84 & 545 & \\
\hline KS01 & A. & \multicolumn{2}{|c|}{ Kume island (Okinawa) } & & 0.92 & 560 & 465 \\
\hline WB31 & d. & \multirow{5}{*}{$138^{\circ} 29.8^{\prime}$} & \multirow{5}{*}{$35^{\circ} 27.0^{\prime}$} & & 0.90 & 520 & 430 \\
\hline WB32 & d. & & & & 0.93 & 520 & \\
\hline WB33 & d. & & & & 0.97 & 520 & \\
\hline WB34 & d. & & & & 0.91 & 515 & 430 \\
\hline WB36 & d. 1 & & & & 0.96 & 540 & \\
\hline IW31 & A. & $137^{\circ} 13.5^{\prime}$ & $36^{\circ} 32.0^{\prime}$ & B-I & 0.99 & 550 & 395 \\
\hline HK05 & A. & $139^{\circ} 6.0^{\prime}$ & $35^{\circ} 13.2^{\prime}$ & \multirow{8}{*}{ C-I } & 1.33 & 540 & \\
\hline HK12 & A. & $139^{\circ} 7.0^{\prime}$ & $35^{\circ} 11.9^{\prime}$ & & 1.38 & 540 & \\
\hline HK28 & A. & $139^{\circ} 8.4^{\prime}$ & $35^{\circ} 11.0^{\prime}$ & & 1.25 & 560 & \\
\hline HK52 & A. & $139^{\circ} 6.1^{\prime}$ & $35^{\circ} 0.4^{\prime}$ & & 1.29 & 520 & 330 \\
\hline HK58 & A. & $139^{\circ} 5.4^{\prime}$ & $35^{\circ} 13.2^{\prime}$ & & 1.14 & 550 & \\
\hline IW11 & B. & $137^{\circ} 12.9^{\prime}$ & $36^{\circ} 32.5^{\prime}$ & & 1.30 & 510 & 360 \\
\hline IW23 & B. & $137^{\circ} 13.4^{\prime}$ & $36^{\circ} 32.3^{\prime}$ & & 1.32 & 525 & 345 \\
\hline WB35 & d. & $138^{\circ} 29.8^{\prime}$ & $35^{\circ} 27.0^{\prime}$ & & 1.06 & 540 & 325 \\
\hline HK47 & A. & $139^{\circ} 1.9^{\prime}$ & $35^{\circ} 12.3^{\prime}$ & \multirow{3}{*}{ A-II } & 0.93 & 525 & 480 \\
\hline HK49 & A. & $139^{\circ} 2.8^{\prime}$ & $35^{\circ} 12.5^{\prime}$ & & 0.92 & 510 & 480 \\
\hline HK62 & A. & $139^{\circ} 5.9^{\prime}$ & $35^{\circ} 6.9^{\prime}$ & & 0.90 & 540 & 420 \\
\hline HK20 & A. & $139^{\circ} 6.4^{\prime}$ & $35^{\circ} 9.2^{\prime}$ & \multirow{3}{*}{ B-II } & 1.00 & 500 & 365 \\
\hline HK45 & A. & $139^{\circ} 2.8^{\prime}$ & $35^{\circ} 14.2^{\prime}$ & & 0.95 & 465 & \\
\hline HK59 & D. & $139^{\circ} 6.6^{\prime}$ & $35^{\circ} 8.9^{\prime}$ & & 1.00 & 500 & 390 \\
\hline HK 10 & A. & $139^{\circ} 8.7^{\prime}$ & $35^{\circ} 12.8^{\prime}$ & \multirow{4}{*}{ C-II } & 1.02 & 505 & 320 \\
\hline HK34 & A. & $139^{\circ} 5.7^{\prime}$ & $35^{\circ} 9.9^{\prime}$ & & 1.02 & 520 & \\
\hline HK64 & B. & $139^{\circ} 2.8^{\prime}$ & $35^{\circ} 9.9^{\prime}$ & & 1.12 & 475 & 400 \\
\hline EN01 & A. & $138^{\circ} 2.1^{\prime}$ & $36^{\circ} 5.3^{\prime}$ & & 1.06 & 500 & 380 \\
\hline
\end{tabular}

*Rocks: A., andesite; B., basalt ; D., dacite; d., dolerite. 


\subsection{Thermomagnetic curves}

Change of saturation magnetization, $J_{\mathrm{s}}\left(H=2.4 \times 10^{5} \mathrm{~A} / \mathrm{m}\right)$, with temperature $T$ were measured between room temperature and $600^{\circ} \mathrm{C}$ by means of a quartz-spring thermomagnetic balance in vacuum of $0.5-0.01 \mathrm{~Pa}$. Rate of heating and cooling is $300^{\circ} \mathrm{C} / \mathrm{hr}$.

Various types of thermomagnetic curves thus obtained were classified into types I and II as well as types A, B, and C (Fig. 1) according to the following criteria :

1) In type $\mathrm{I}$, the Curie temperature $T_{\mathrm{C}}$ determined from initial heating curve (hereafter called "initial $T_{\mathrm{C}}$ ") is nearly coincident with $T_{\mathrm{C}}$ determined from thermomagnetic

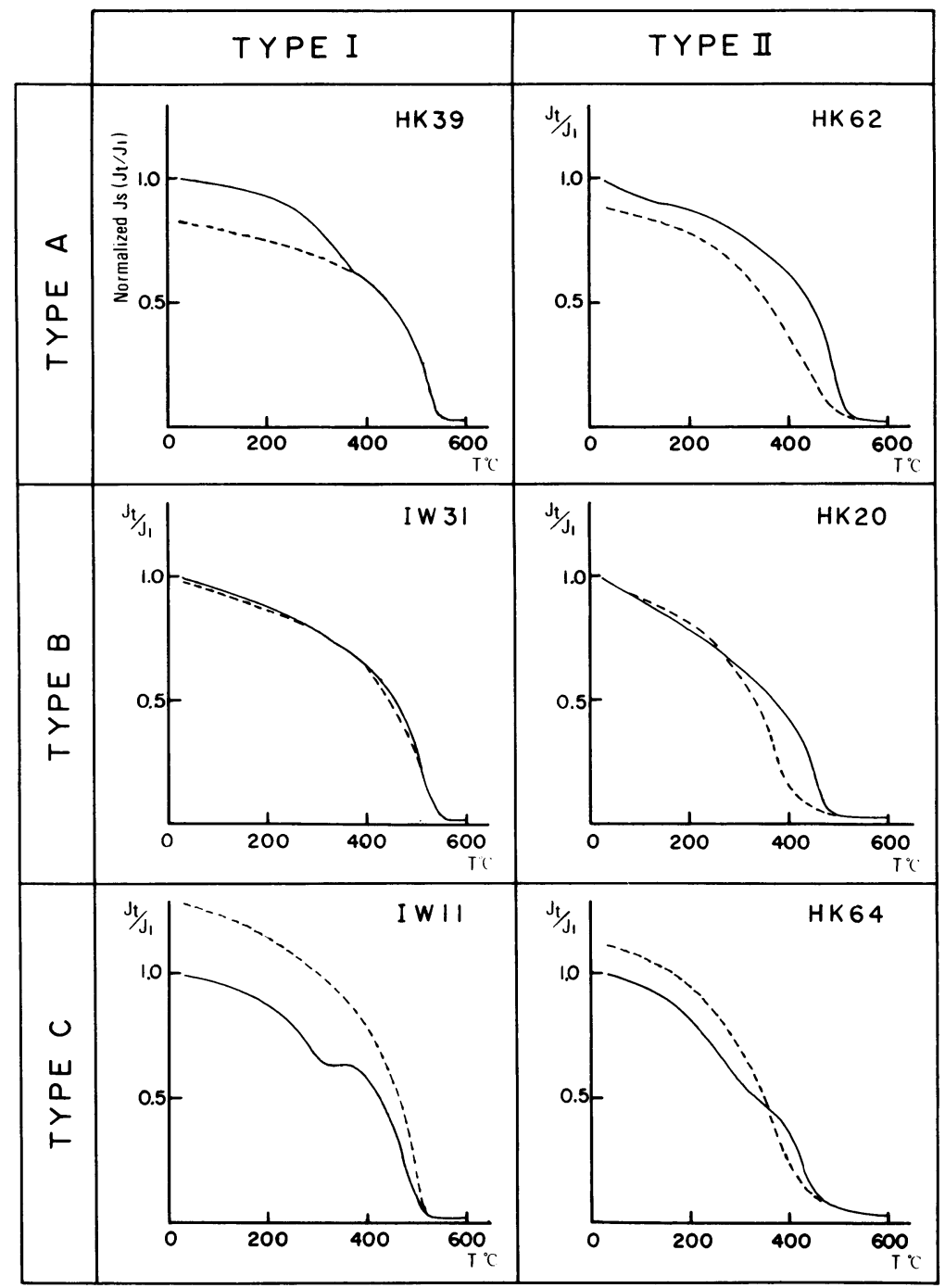

Fig. 1. Six typical $J_{\mathrm{s}}-T$ curves of titanomaghemite-bearing rocks. Solid and dotted curves denote heating and cooling, respectively. See text reading experimental conditions. 
curve cooled from the maximum temperature of $600^{\circ} \mathrm{C}$ (called "cooling $T_{\mathrm{C}}$ "). The cooling $T_{\mathrm{C}}$ is apparently lower than its initial $T_{\mathrm{C}}$ in type II.

2) $J_{2}$, saturation magnetization at room temperature after a heating-cooling cycle, is smaller than $J_{1}$, saturation magnetization at room temperature before heating, in type A. $J_{2}$ is equal to $J_{1}$ in type $\mathrm{B}$ and is larger than $J_{1}$ in type C.

Six different types are distinguishable by combination of these twofold classifications. Type B-I curve is reversible in a cycle of heating and cooling.

\subsection{Heat-treatment at higher temperatures $\left(680^{\circ}-950^{\circ} \mathrm{C}\right)$}

Twenty-seven selected samples were heated at $680^{\circ}-950^{\circ} \mathrm{C}$ in vacuum of $0.5-0.01 \mathrm{~Pa}$. Thermomagnetic analysis was repeated after the samples were cooled to room temperature. The Curie temperature $T_{\mathrm{C}}$ of such heat-treated samples is substantially lower than the initial $T_{\mathrm{C}}$ of the original samples. $T_{\mathrm{C}}$ of heat-treated samples is called "reduced Curie temperature" and listed in Table 1 together with the initial $T_{\mathrm{C}}$ of the original samples.

Figure 2 shows relation between $J_{2} / J_{1}$ and reduced $T_{\mathrm{C}}$ with type I samples (solid marks) and type II (hollow marks). It is noteworthy that $J_{2} / J_{1}$ values are roughly inversely proportional to the reduced $T_{\mathrm{C}}$, while $J_{2} / J_{1}$ of type I is generally larger than that of type II. Significance of this tendency will be discussed later.

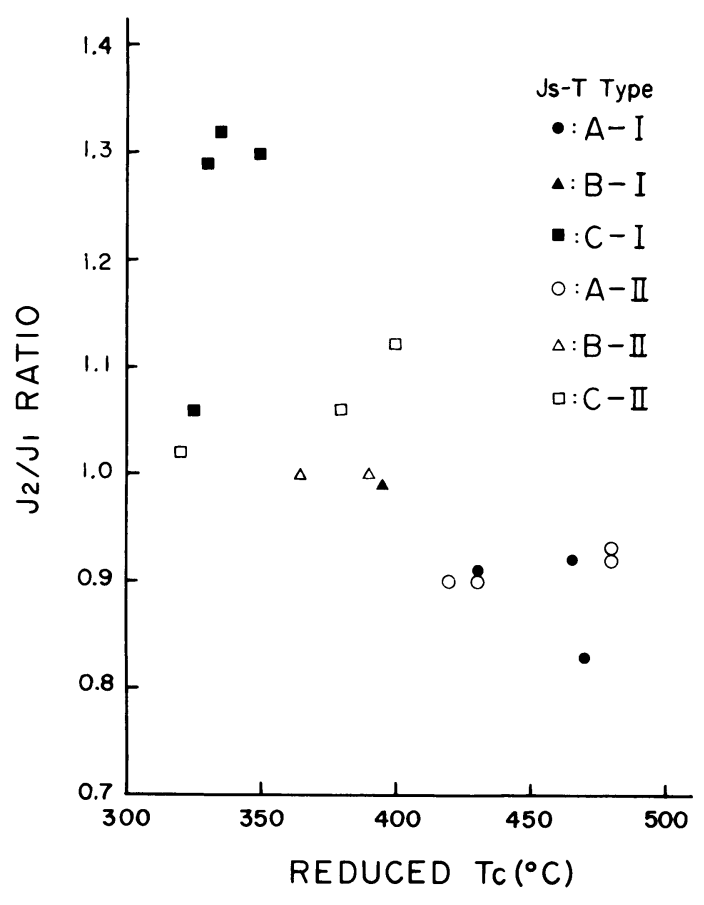

Fig. 2. Correlation between reduced $T_{\mathrm{C}}$ and $J_{2} / J_{1}$ ratio. Value of $J_{2} / J_{1}$ ratio is determined from $J_{\mathrm{s}^{-}}$. $T$ curve of the initial sample. The $J_{2} / J_{1}$ ratios of type I (solid marks) and type II (hollow marks) range $0.83-1.32$ and $0.90-1.12$, respectively. 


\section{Microscopic Observations of Thermal Processes}

\subsection{Experimental procedure}

A pair of the original (unheated) and heated samples were mounted in raisin and polished to be examined under a reflection microscope and by an electron-probe microanalyzer (EPMA). Due to restriction of magnification only phenocryst-size opaque minerals were investigated by this method. The original samples contain partially maghemitized titanomagnetite. Figure 3 shows an example of highly maghemitized grains. Titanomaghemite (bright) occurs only partly, in several volume percent of titanomagnetite (dark). Ti content of titanomaghemite is slightly higher than that of titanomagnetite, indicating that oxidation proceeds by bleaching of $\mathrm{Fe}$ ions.

(a)

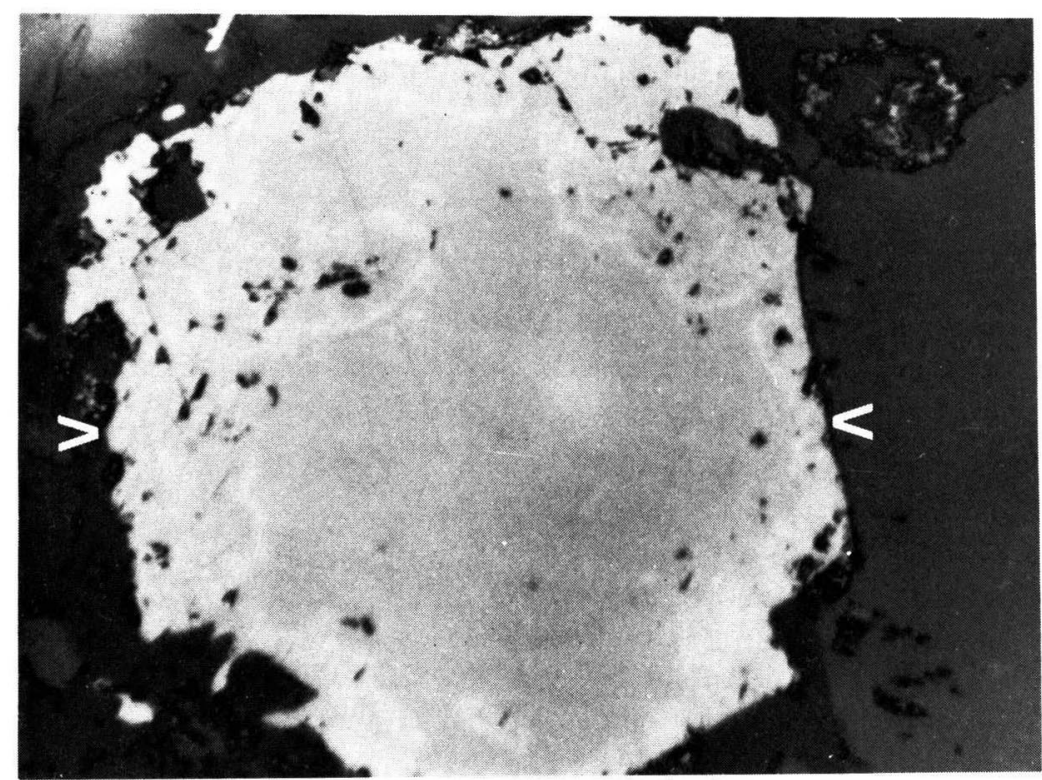
$10 \mu$

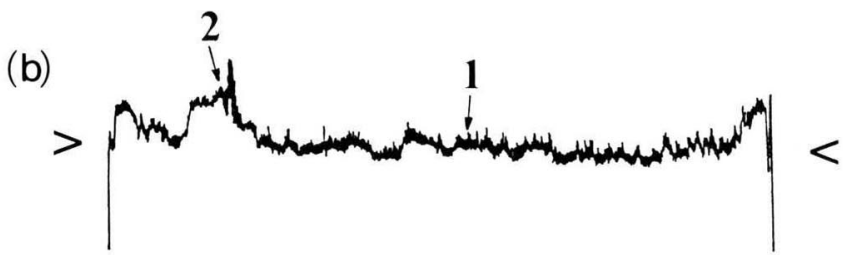

Fig. 3. Initial state; unheated KS01. (a), Partially maghemitized titanomagnetite. titanomagnetite (inside, gray) and titanomaghemite (marginal, white-gray) are seen. (b), Titanium profile on the marked line; $\mathbf{1}, \mathrm{TiO}_{2}=11.6 \mathrm{wt} \%, 2, \mathrm{TiO}_{2}=15.4 \mathrm{wt} \%$. 


\subsection{Unmixing stage}

Photomicrograph of the same sample after heating at $250^{\circ} \mathrm{C}$ (Fig. 4) indicates that the oxidized titanomagnetite decomposes at such low temperatures. Lamellae of ilmenohematite are clearly seen in the margin of titanomagnetite grain.

If the same sample is heated at $390^{\circ} \mathrm{C}$, ilmenohematite lamellae grow longer toward the inner part of titanomagnetite crystal (Fig. 5), while the core of titanomagnetite is apparently unchanged. After the sample is heated at above $390^{\circ} \mathrm{C}$, trellis lamellae are formed all over the titanomagnetite grain (Fig. 6a). Each intergrowth consists of sandwiches of ilmenite and ilmenohematite (Fig. 6b).

A profile of Ti-content obtained by EPMA (Fig. 6c) indicates that unmixing in the right-hand side is stronger than in the left-hand side. Background level of $\mathrm{Ti}$ is lower in the right-hand side than in the left, implying that Ti-content in titanomagnetite (spinel-cubic phase) decreases as unmixing proceeds. After the sample is heated at $600^{\circ} \mathrm{C}$, unmixing further proceeds and ilmenite lamellae increase by consuming lamellae of ilmenohematite (Fig. 7). After heating at $680^{\circ} \mathrm{C}$, ilmenite is dominating (Fig. 8).

\subsection{Mixing stage}

Heating at higher temperatures causes mixing of ilmenite and ilmenohematite with titanomagnetite. In some samples, the mixing takes place at temperatures above $500^{\circ} \mathrm{C}$, and in most samples at temperatures higher than $700^{\circ} \mathrm{C}$. Mixing starts with disappearance of ilmenite lamellae (Fig. 9), and is followed by formation of Ti-rich titanomagnetite in the original titanomagnetite to cause coexistence of two phases of titanomagnetite (Fig. 10).

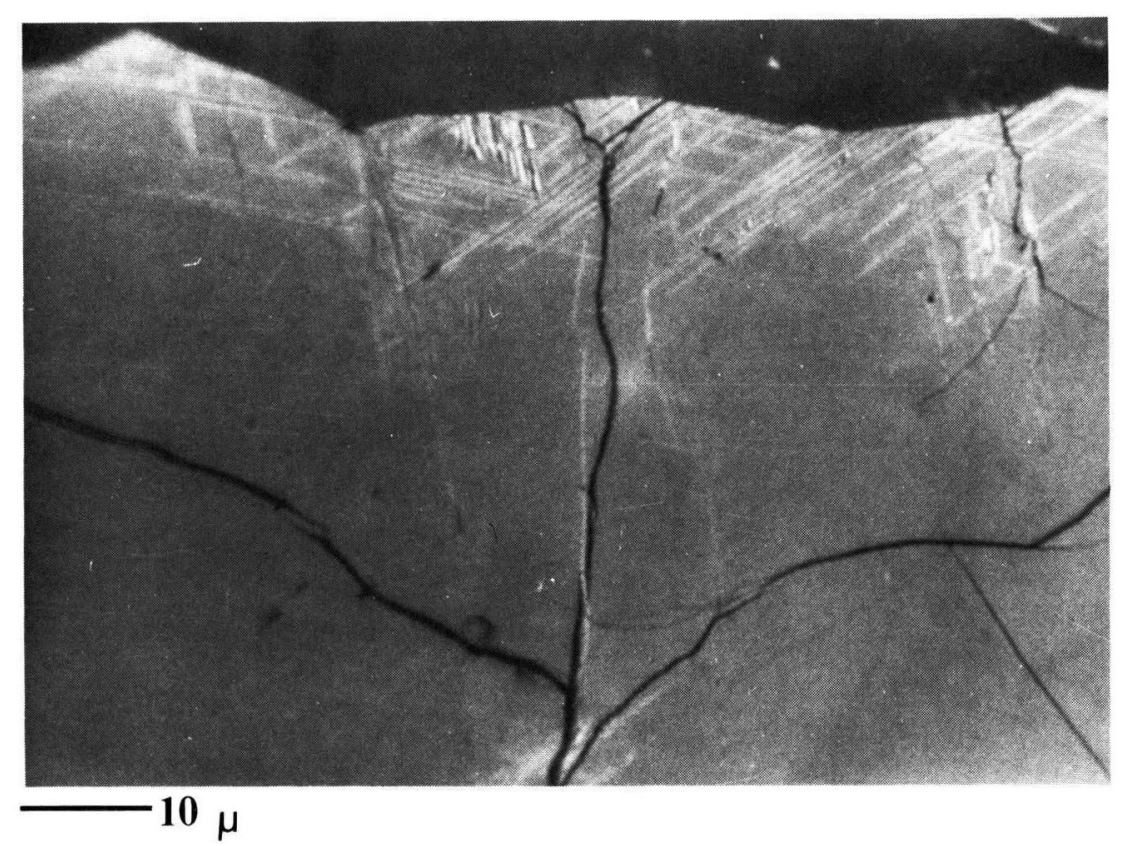

Fig. 4. Early stage of unmixing; KS01 heated at $250^{\circ} \mathrm{C}(0.5 \mathrm{~Pa}, 3 \mathrm{hr})$. Titanomagnetite (lower, gray) and unmixed products from titanomaghemite (marginal part) are seen. White trellis lamellae are ilmenohematite. 


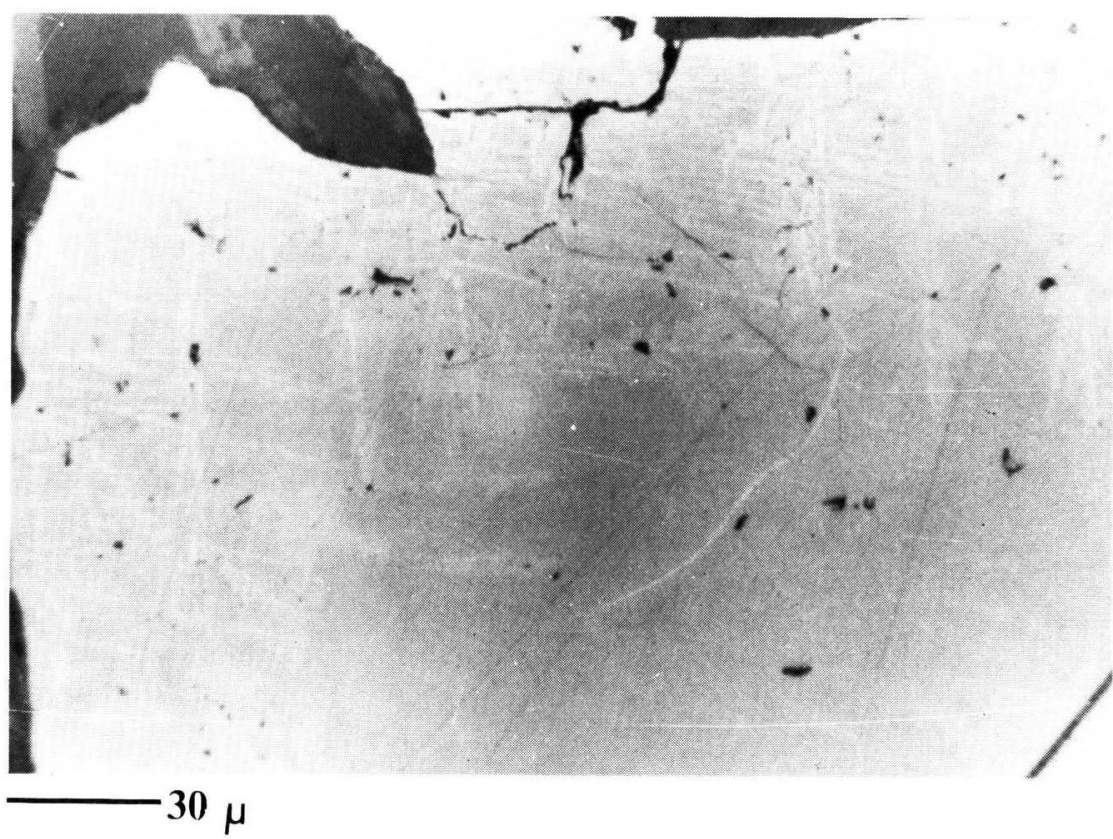

Fig. 5. Slightly advanced unmixing; KS01 heated at $390^{\circ} \mathrm{C}$. Ilmenohematite lamellae (white) apparently invade into titanomagnetite part (gray).

Eventually these two phases are homogenized (mixed) to form nearly uniform titanomagnetite (Figs. 11 and 12).

\subsection{Relevance of mineralogical changes to thermomagnetic behavior}

Microscopic observation shows that temperatures at which unmixing and mixing proceed vary with samples and difference in types of thermomagnetic curves depends primarily upon such variations in the critical temperatures.

Opaque mineral in type I samples heated at $600^{\circ} \mathrm{C}$ are still very heterogeneous. The cooling $T_{\mathrm{C}}$ is therefore nearly equal to the initital $T_{\mathrm{C}}$ in type $\mathrm{I}$. Mixing proceeds at temperatures much higher than $600^{\circ} \mathrm{C}$.

On the contrary, opaque minerals in type II samples are homogeneous titanomagnetite after heating at $600^{\circ} \mathrm{C}$. Such mixed titanomagnetite has higher Ti-content than unmixed stage of this titanomagnetite, and therefore, the cooling $T_{\mathrm{C}}$ of type II is lower than its initial $T_{\mathrm{C}}$. At least, the difference (thermal behavior between type I and type II) seems to be neither due to Ti-content of titanomagnetite nor to maghemitization degree of the mineral. Because, these differences are observed among samples with various Ti-content (Fig. 2).

Distinction among samples of types A, B, and C seems to be correlatable to Ti-content of titanomagnetite, because results of the present thermomagnetic analyses indicate rough inverse correlation between $J_{2} / J_{1}$ and reduced $T_{\mathrm{C}}$ (Fig. 2). As $T_{\mathrm{C}}$ of mixed phase is roughly inversely proportional to Ti-content in titanomagnetite, type A sample is the richest in $\mathrm{Ti}$ and type $\mathrm{C}$ is the poorest in $\mathrm{Ti}$. 


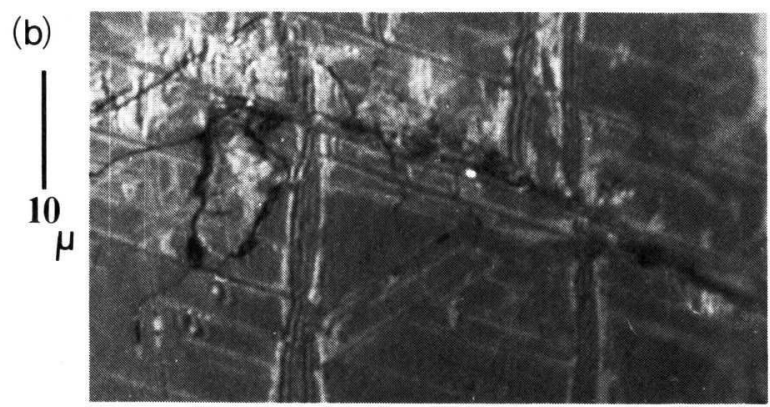

(a)

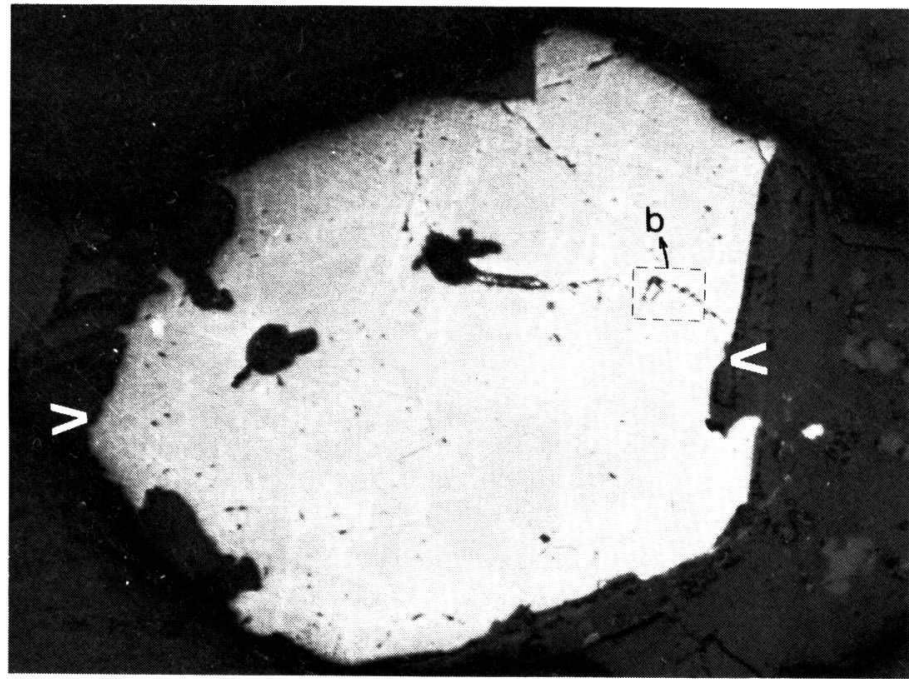

$50 \mu$

(c)

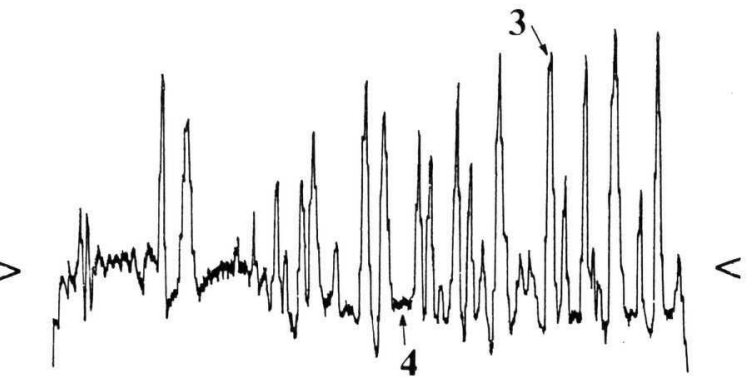

Fig. 6. Middle stage of unmixing; KS01 heated at $390^{\circ} \mathrm{C}$. (a), Whole-grain intergrowth. (b), Highly magnified photograph (dotted area in (a)). Titanomagnetite (gray), ilmenohematite (white) and ilmenite (dark) are seen. Ilmenite is sandwiched between ilmenohematite lamellae. (c), Titanium profile on the marked line; $3, \mathrm{TiO}_{2}=38.6 \mathrm{wt} \%, 4, \mathrm{TiO}_{2}=6.4 \mathrm{wt} \%$. 


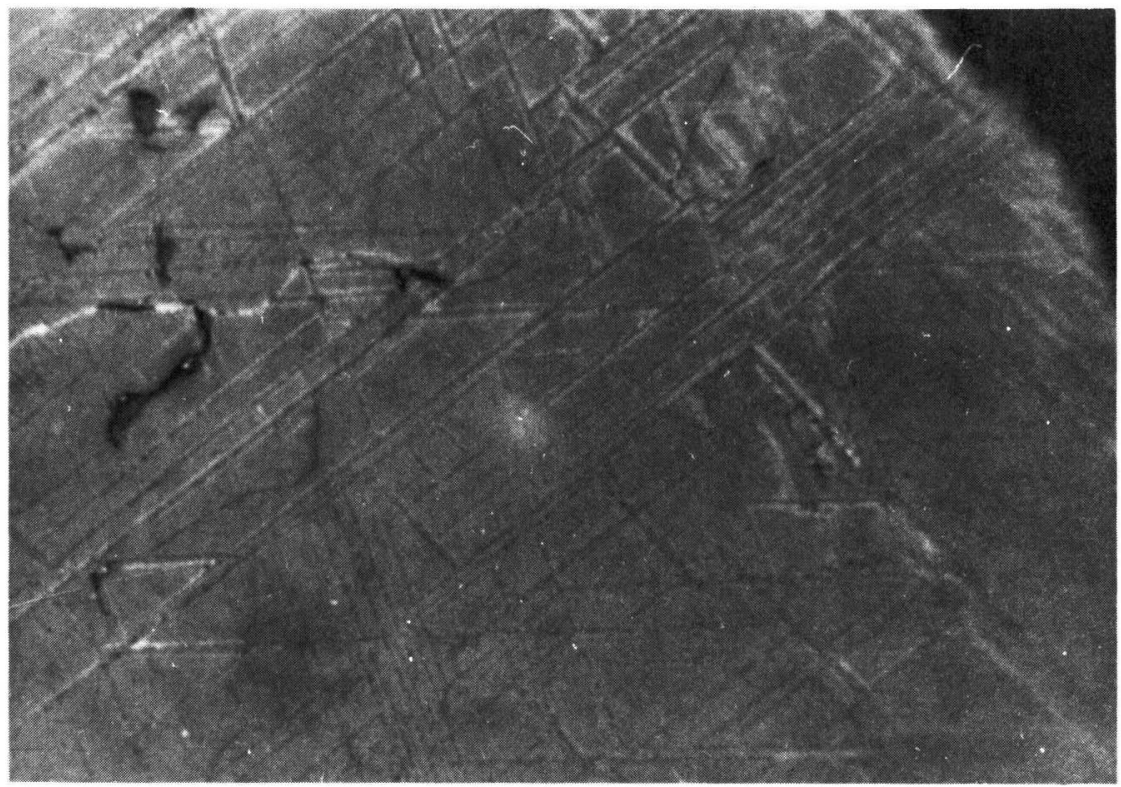

$10 \mu$

Fig. 7. Middle to late stage of unmixing; $\mathrm{KS} 01$ heated at $600^{\circ} \mathrm{C}$. Ilmenite lamellae (dark) grow, and ilmenohematite (white) decreases. The former has direct contact to titanomagnetite (gray).

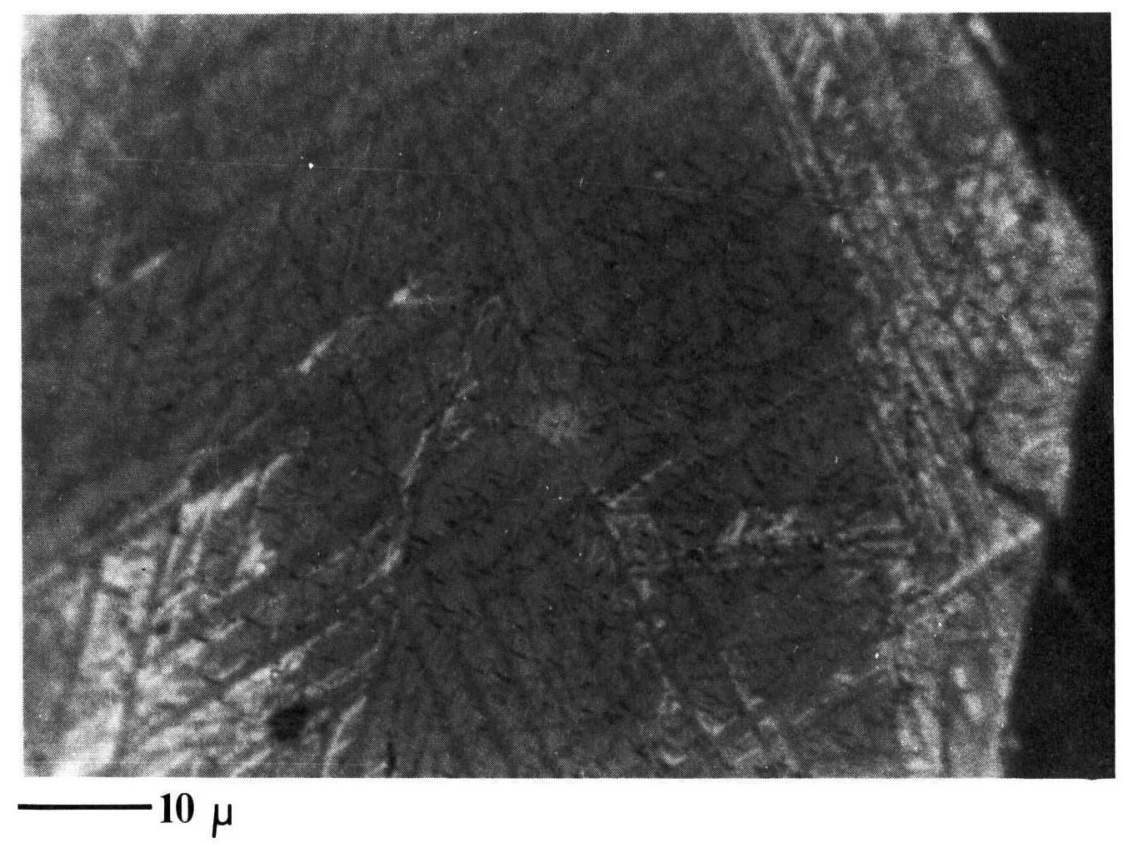

Fig. 8. Late stage of unmixing; KS01 heated at $680^{\circ} \mathrm{C}(0.5 \mathrm{~Pa}, 1 \mathrm{hr})$. Ilmenite lamellae (dark) become dominant. Some spinel or rutil (unidentified, small black whiskers) is seen. 


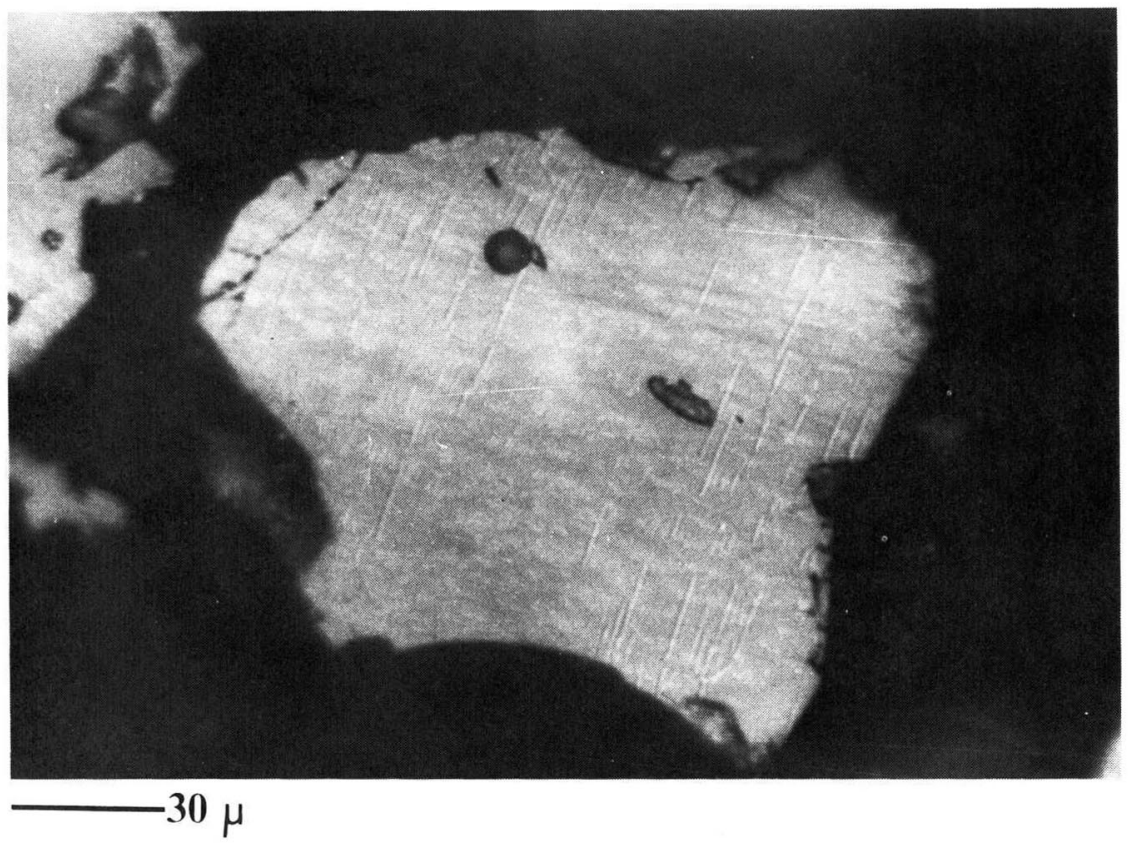

Fig. 9. Beginning of mixing; $\mathrm{HK} 20$ heated at $680^{\circ} \mathrm{C}(0.5 \mathrm{~Pa}, 3 \mathrm{hr})$. Ilmenite lamellae are mixed into titanium-rich titanomagnetite (dark patches and checkers). Remaining lamellae are ilmenohematite (white).

The above-mentioned thermal behaviors of titanomagnemite-bearing rocks from land are in remarkable contrast to those of submarine pillow basalts. Origin of the contrast is due to be larger grain size (discussed in the next section) and smaller degree of maghemitization in land rocks than in submarine pillow basalts.

\section{Effect of Grain Sizes on the Thermomagnetic Behavior}

The present investigation so far described is concerned with the whole rock fragments for thermomagnetic analyses and with phenocryst-size minerals for microscopic examination. However, the rocks contain fine grains of ferromagnetic minerals in groundmass. Role of fine-grained titanomagnetite is investigated here.

\subsection{Sample preparation}

Samples used in the thermomagnetic analyses described above are the whole-rock samples of about $1 \mathrm{~mm}$ in diameter which is pulverized and sieved from fragments of rocks. They are ground and washed in acetone to prevent oxidation to grains of about $0.5 \mathrm{~mm}$ in diameter. Ferromagnetic components are extracted by a hand magnet to obtain phenocryst-size samples. As described already, the phenocryst-size samples consist of partially maghemitized titanomagnetite.

Remaining fractions consist of various minerals, including fine-grained (less than several microns) ferromagnetic minerals, that are mostly maghemitized titanomagnetite 
(a)
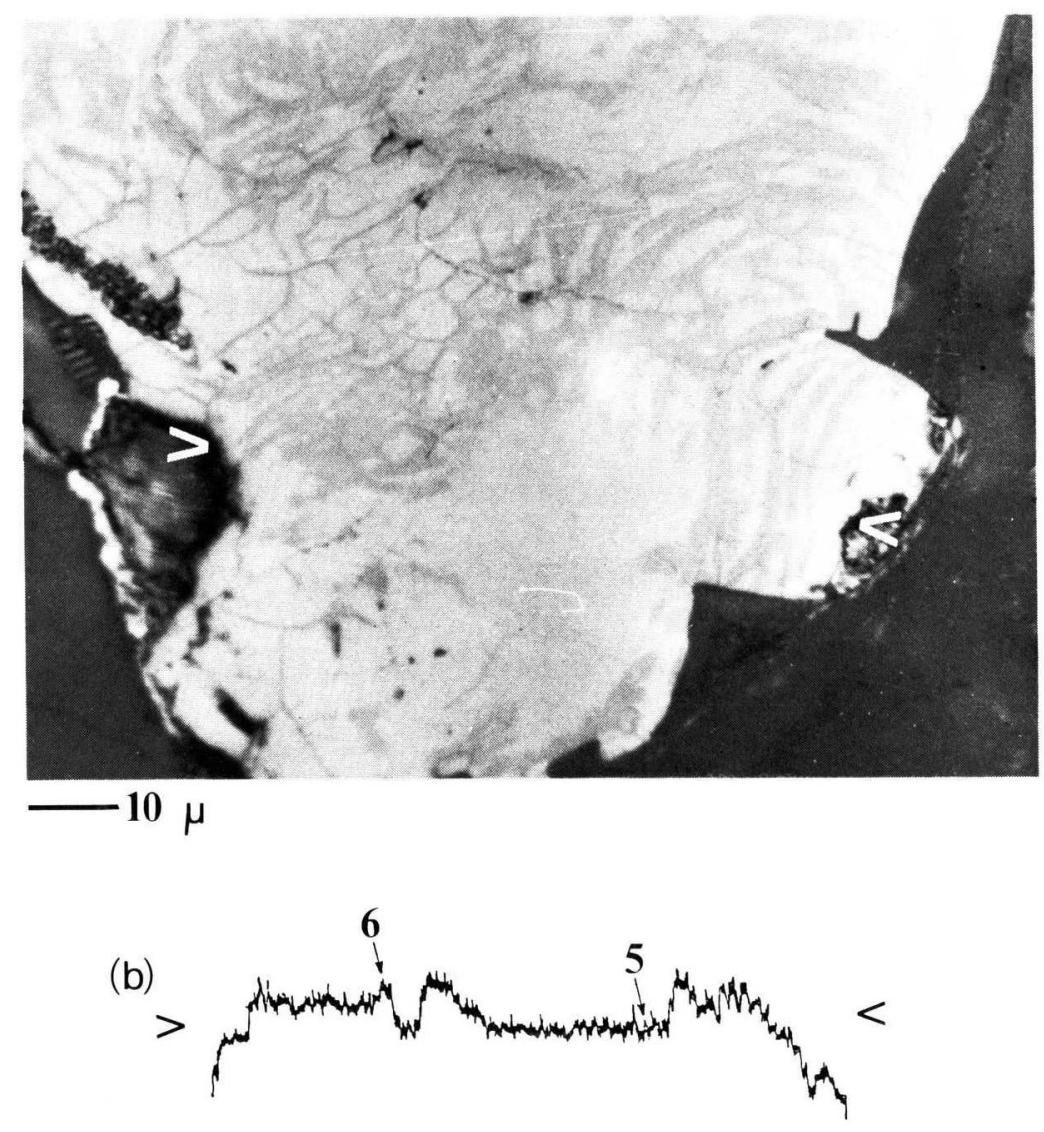

Fig. 10. Middle stage of mixing; KS01 heated at $800^{\circ} \mathrm{C}(0.01 \mathrm{~Pa}, 1 \mathrm{hr})$. (a), Titanomagnetite with two phases. (b), Titanium profile on the marked line; 5, $\mathrm{TiO}_{2}=11.1 \mathrm{wt} \%, 6, \mathrm{TiO}_{2}$ $=12.0 \mathrm{wt} \%$.

(titanomaghemite). They are finely pulverized in acetone and ferromagnetic components are extracted to obtain fine- $A$ samples. Besides, the phenocryst-size sample is pulverized to fine particle size to prepare fine-B samples (Fig. 13).

\subsection{Thermomagnetic analyses}

$J_{\mathrm{s}}-T$ curves of the whole-rock, phenocryst-size, fine-A and fine-B samples are represented in Fig. 14. Thermomagnetic behavior of the whole-rock is nearly identical to that of phenocryst-size samples, indicating that contribution of groundmass to the bulk saturation magnetization is negligibly small.

Thermomagnetic curves of fine-A and fine-B are similar to each other, but distinctly different from those of the whole-rock and phenocryst-size samples. As no chemical changes are expected in the grinding procedure from phenocryst-size to fine-B samples, different thermomagnetic behavior of fine-B samples compared to phenocryst-size samples may be caused by difference in grain size, i.e. as the grain size becomes smaller, rate of 


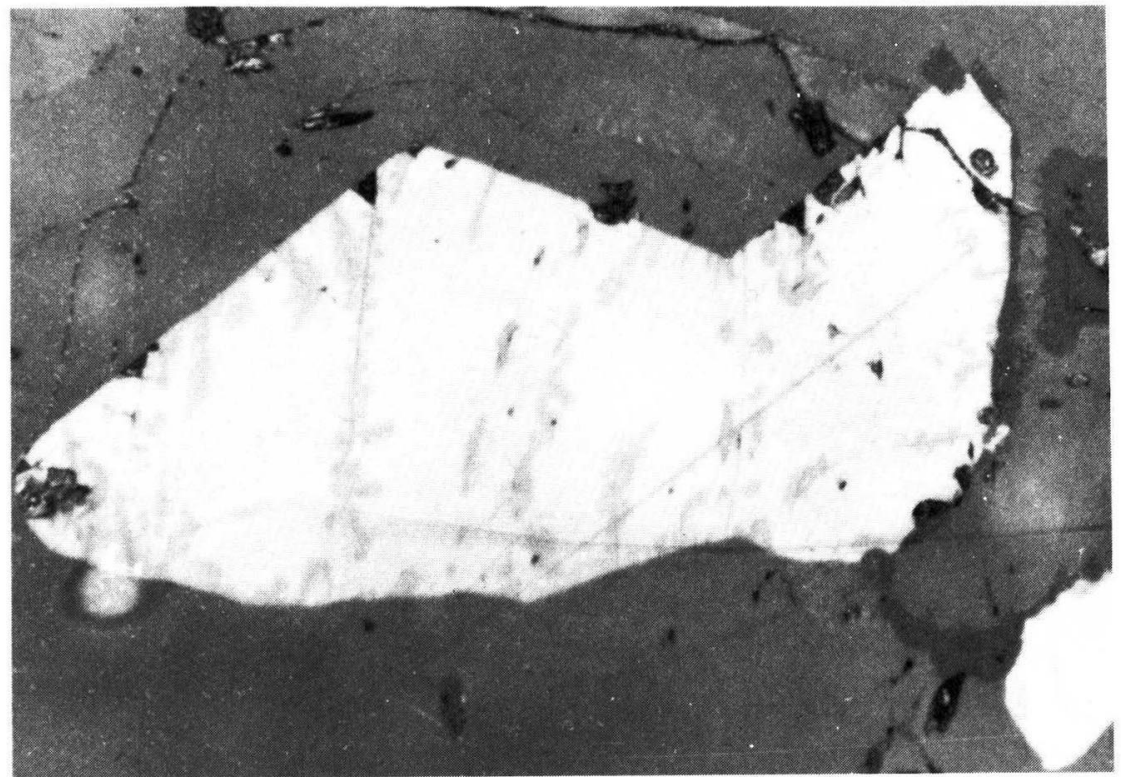

Fig. 11

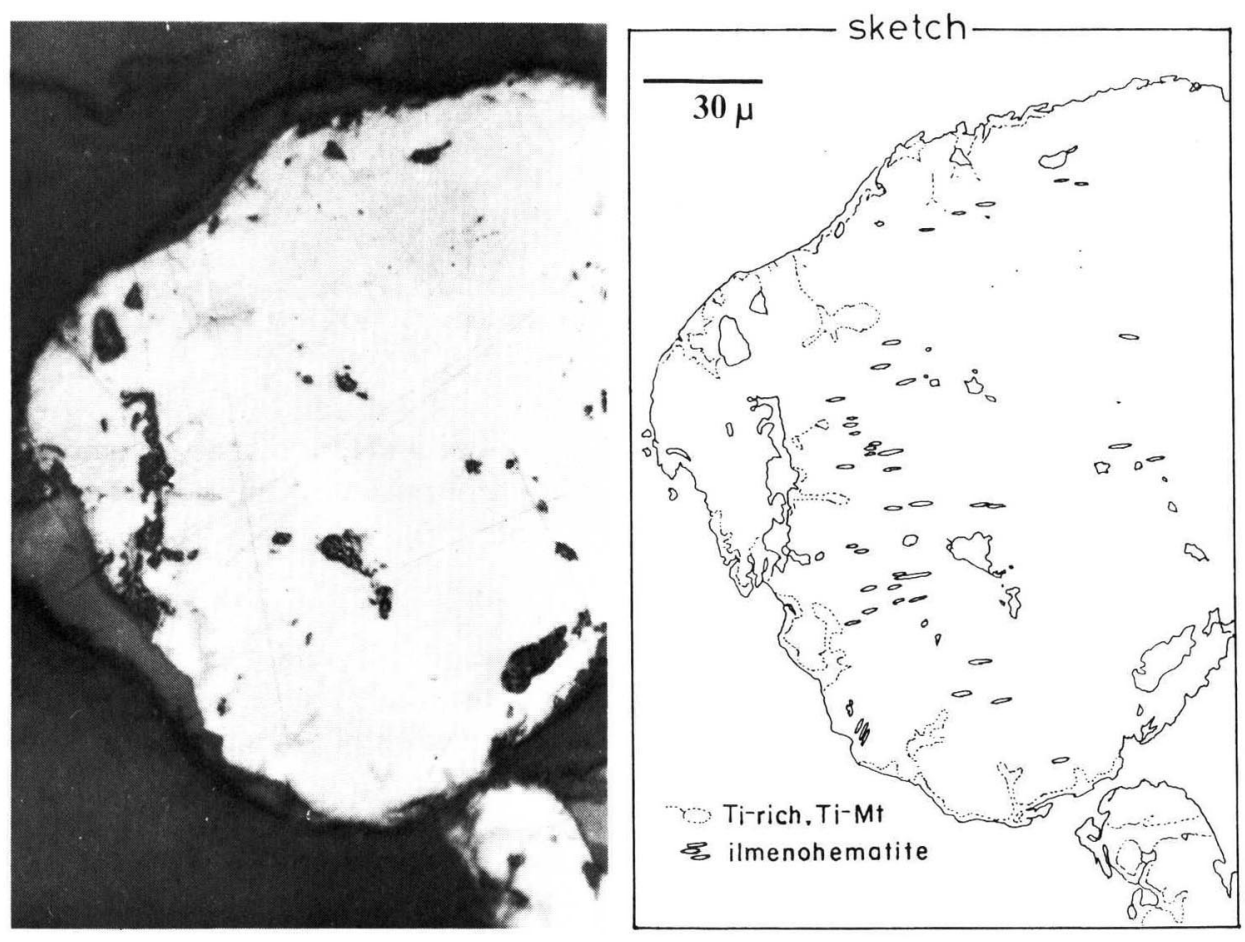

Fig. 12 
mixing at $600^{\circ} \mathrm{C}$ decreases so substantially that the cooling $T_{\mathrm{C}}$ of fine samples is not reduced by formation of Ti-rich titanomagnetite owing to mixing. Unmixed samples often have higher saturation magnetization, as shown in thermomagnetic curves of submarine basalts.

\section{Summary}

(1) Titanomaghemite decomposes at temperatures ranging from $200^{\circ}$ to $600^{\circ} \mathrm{C}$ to form intergrown exsolution lamellae of ilmeno-hematite, ilmenite in titanomagnetite.

(2) The unmixed intergrowth is homogenized to titanomagnetite at temperatures between $500^{\circ}$ and $800^{\circ} \mathrm{C}$.

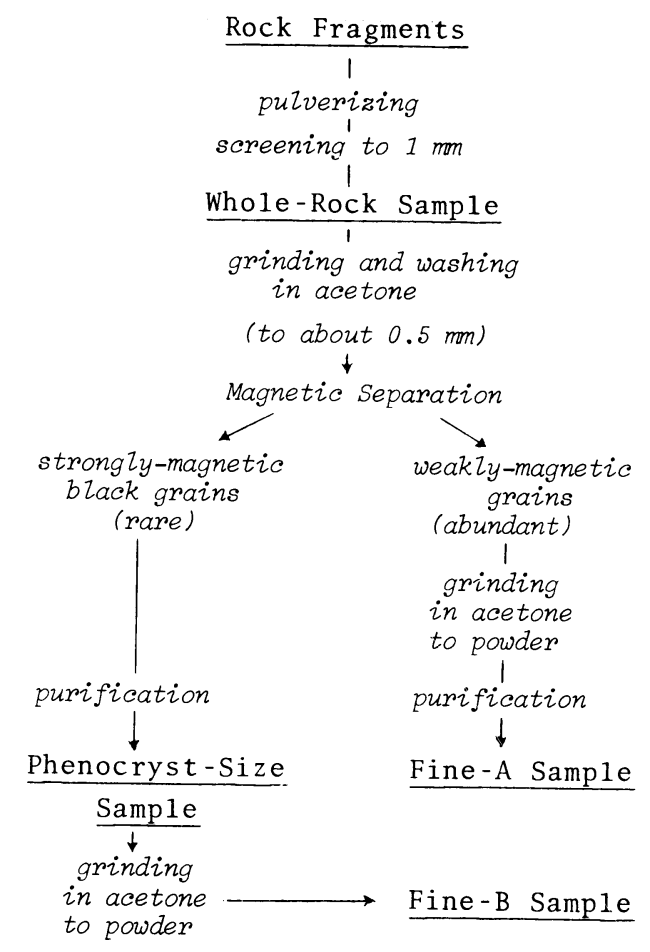

Fig. 13. Sample preparation procedure.

Fig. 11. Middle to late stage of mixing; KS01 heated at $800^{\circ} \mathrm{C}(0.01 \mathrm{~Pa}, 1 \mathrm{hr})$. Most part of the grain is homogenized. Titanium-rich titanomagnetite remains along rims and cracks of the grain in a particular shape.

Fig. 12. Late stage of mixing; $\mathrm{KS} 01$ heated at $950^{\circ} \mathrm{C}(0.01 \mathrm{~Pa}, 1 \mathrm{hr})$. Almost completely homogeneous titanomagnetite containing small inclusions (see sketch). 

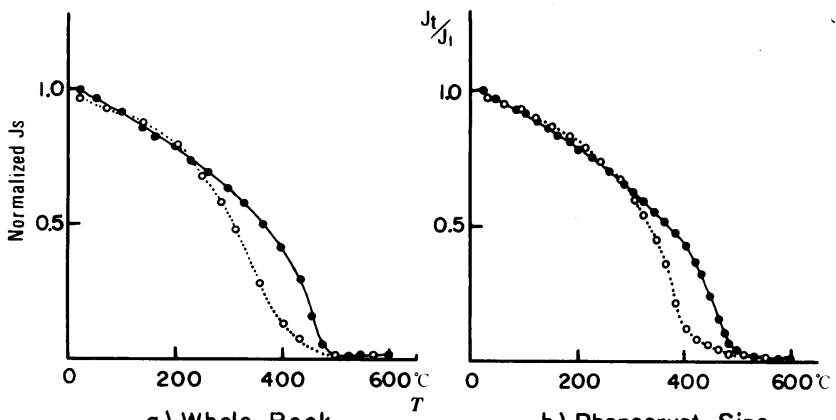

a) Whole-Rock

b) Phenocryst-Size

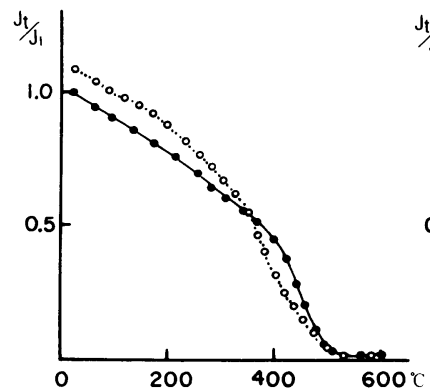

c) Fine-A

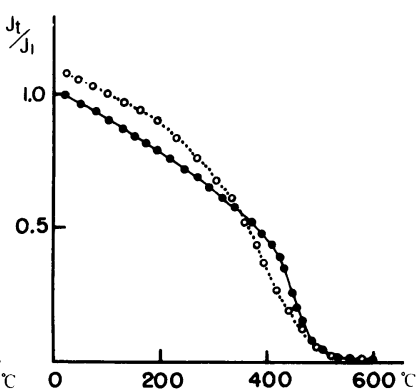

d) Fine-B

Fig. 14. Thermomagnetic curve of each sample prepared from a rock sample (HK20). Solid circle and line denote heating, and open circle and dotted line cooling. Experimental conditions are the same as Fig. 1.

(3) Rate of mixing depends upon grain size of titanomagnetite. If the size is larger than one-tenth of millimeter, mixing usually proceeds at temperatures at or slightly lower than about $600^{\circ} \mathrm{C}$ in an experimental time interval. If the size of titanomagnetite is much smaller, mixing is observed only after it is heated at a temperature higher than $650^{\circ} \mathrm{C}\left(680^{\circ}\right.$ to $900^{\circ} \mathrm{C}$ ), although the rate of mixing seems to depend also upon chemical and crystallographic conditions of titanomagnetite.

(4) Various thermomagnetic behaviors of natural rocks may be explained by combination of unmixing and mixing during heating.

Professor Kan-ichi Momose of Shinshu University has kindly encouraged and instructed me throughout the present work and read the manuscript. The author thanks Professor Kazuo Kobayashi of Ocean Research Institute, University of Tokyo, for critical reading of the manuscript. The author is grateful to Professor Yoshimasu Kuroda and his staff of Shinshu University for their help to microprobe analysis. 


\section{REFERENCES}

AKImoto, S. and I. KuSHIRo, Natural occurrence of titanomaghemite and its relevance to the unstable magnetization of rocks, J. Geomag. Geoelectr., 11, 94-110, 1960.

Katsura, T. and I. Kushiro, Titanomaghemite in igneous rocks, Am. Mineral., 46, 134-145, 1961.

OzIma, M. and E. LARSON, Study on irreversible change of magnetic properties of some ferromagnetic minerals, $J$. Geomag. Geoelectr., 19, 117-127, 1967.

OzImA, M. and E. E. LARSON, Low- and high-temperature oxidation of titanomagnetite in relation to irreversible changes in the magnetic properties of submarine basalts, J. Geophys. Res., 75, 1003-1017, 1970.

Readman, P. W. and W. O'Reilly, The synthesis and inversion of non-stoichiometric titanomagnetites, Phys. Earth Planet. Inter., 4, 121-128, 1970.

SASAJIMA, S., $\gamma$-titanohematite in nature and the role they play in rock-magnetism, J. Geomag. Geoelectr., 12, $190-215,1961$.

Sasajima, S. and K. Maenaka, Paleomagnetic stratigraphy of Neogene Tertiary in Kume island, Report of structural geology on G.D.P., 1, 75-82, 1973 (in Japanese). 